\title{
Assessment of Diamondiferousness Perspectives of East-Europian Platform according to the Data of Sounding from Space
}

Zuev, V.M. ${ }^{1}$, Serokurov, Y.N. ${ }^{2}$, and Kalmykov, V.D. ${ }^{2}$

1. ALROSA Co. Ltd., Sakha (Yakutia), Russia

2. UNEGEO, Moscow

East-Europian Platform is considered at present as a new diamondiferous province. Traditional methods of diamond forecast and prospecting within East-Europian Platform are complicated by the fact that on considerable areas within its limits there exist developed thick sedimentations of Perm and Meso-Kainozoic ages, overlaying potentially kimberlite-hosting thick layers. On vast areas there are covering glacier sedimentations shifted from the north of the Platform. In central and southern parts of it geologic investigation is complicated by considerable technogenous load on landscape due to intensive farming and a thick net of populated settlements and industrial enterprises.

A still sufficiently sparse net of structural bore holes does not allow to properly shed light on the features of sedimental cover' and basement's composition. Gravimetric and airborne surveys of required detailed form cover not all potentially diamondiferous sites of the Platform for certain. There is either no regular net of seismic deep sounding.

In the present work we consider the possibility of revealing favourable structural situations for localization of diamondiferous taxons not larger than rank "region" within the East-European Platform on the basis of analysis of space sounding materials of small and average resolution. They are suitable for mapping of diverse order tectonic structures providing penetration of kimberlite and other types of magma of mantle nature into upper levels of the Earth's crust. Analysis technology of these materials for forecast and prospecting of primary diamond deposits has been worked out on the basis of known diamondiferous areas of the world. In the basis of it there are traditional at ore forecast principles of similarity, providing for application of the revealed within the known diamondiferous areas indications, totality of which makes it possible to distinguish them from the surrounding space containing no ore. The indications are revealed with the help of visual and computer decoding of space photographs; specialized qualitative and quantitative processing of initial decoding data. Interpretation was performed on the basis of available geologic-geophysical data.

Specialized structural map of East-European Platform, drawn up by us on the materials of data processing of small and average resolution space photographs decoding with application of interpretation results of airborne and gravimetric maps of 1:2 500000 scale, served as a basis for picking out perspective areas. There are reflected only those elements of of the Platform's structure which, in our opinion, to the greatest degree promote migration of mantle rocks (including kimberlites as well) to the surface of the Earth. The original character of the map lies in the fact that it shows diverse order (with the diameter from the first thousands of metres to hundreds of $\mathrm{km}$ ) radial-concentric dislocations, located sufficiently regularly relatively each other, as the main structural elements of the Platform.

Endogenic processes are accompanied by the formation of various geodynamic centres. Each of "energy-generating centres" in the result of numerous impulse discharging of accumulated energy creates in overlaying thicknesses organized systems of divisibility of the Earth's crust and lithosphere as a whole. At the level of erosional section they represent poli-circled (multi-ring ) systems of radial-concentric dislocations. Diverse order and diverse rank systems of radial- 
concentric dislocations everywhere display themselves as a compulsory component of geological environment tectonic frame and must be considered as reliable tectonophysical indicators of structure-forming processes of the centre type. These regularities, as our investigations have indicated, are traced during generalization of images in smaller and small scales, and the majority of known at present elements turn out to be fragments of radial-ring systems of this or that scale.

Analysis of kimberlites allocation regularities on a number of ancient platforms of the world allows to conclude that industrial diamondiferous areas in the regional plan are monitored by the following structural factors:

1. Arc and radial zones being part of gigantic systems (up to $10000 \mathrm{~km}$ in diameter) which, probably, represent main frame structures affecting evolutional coming into being of continental Earth's crust in the course of the whole history of its development. As a rule they stipulated borders of the largest lithospheric blocks, having been formed in different time and in different from each other regimes, as well as places of blocking up largest zones of linear dislocation of the crust different in age Proterozoic folding belts, Riphean and Paleozoic riftogenic structures in the basement, Meso-Kainozoic billows and chains of local uplifts in sedimental cover of platforms; folding belts in the frame of platforms. These zones can be considered as the most abyssal, mobile and penetrating parts of the crust for heat and mass transfer on the whole, stipulating different physical and chemical transformations within its limits in the course of lasting geological period of time.

On the territory under evaluation we have revealed East-Europian radial-concentric system, the centre of which is located $300 \mathrm{~km}$ north-west of Moscow.

2. By arc and radial elements, making up ovoid-radial structures with the diameter of up to the first thousands of kilometres, within the East-European Platform there were revealed seven such structures - Ladozhskaya, Mezenskaya, middle-Volzhskaya, Volgo-Uralskaya, Donskaya, Dneprovskaya and Vislenskaya. Epicentres of these structures clearly are drawn to the knots of arc and radial constituents' intersection of East-European system, and composing them elements represent mobile and penetrable zones of violation of the second order crust unbrokenness, which also serve as channels of increased penetrability.

Authenticity of existence of ovoid-radial structures has been proved by means of spatial correlation of making them up elements with available geological, geophysical and orographic data. In particular, they find reflection in the field of the second derivative of gravitational potential (V $\Delta$ ), where along the periphery of ovoids' kernels there locate well-defined negative anomalies. Such kind of picture, according to the direct task of gravimetry, is typical for deep occurring spherical sources with positive excessive density. In anomalies of the force of gravity (in reduction of Buge) and their transformations to ovoids, on the whole, there correspond positive anomalies. Near the epicentres of ovoids there is visible "vortical" dislocation of middle-frequency gravitational and magnetic anomalies, and in the space between them there are clearly indicated extended linear anomalies frequently concurring with the zones of linear dislocations of the basement. It is not excluded that exactly ovoid-radial structures represent an important structural factor of control of diamondiferous subprovinces, the traditional definition for which is "large geological blocks of ancient platforms with the same age of cratonization, history of geological development and intensity of tectono-magmatic activization occurrences" [1].

3. By ring structures with diameter $150-220 \mathrm{~km}$, which in general case may form due to different reasons, including the affect on the Earth's crust of mantle diapirs over which evolutional processes leading to formation of diamondiferous regions took place. Structural elements making it possible to reveal ring structures of this class in the regions of development of mighty thicknesses of sedimentary cover occur only by strokes in the employed by us at this stage materials of space 
photography of small and average resolution. At this stage it is also difficult to classify the revealed structures by perspectiveness according to other additional indications, among which - availability and absence of radial-concentric dislocations, their dome and depression nature, etc. A reliable indication of attribution such kind of structures to potentially diamondiferous ones in this scale is only their position in intersection knots of penetrable zones of much higher order.

Similar texture and stability of sizes of the revealed radial-ring structures on all diamondiferous areas of the world testifies about close nature of conditions of their origin and development. The reflection of composing them elements in modern landscapes tells about repeated renewal of violations due to abyssal energy up to the present days.

Into the basis of forecast zoning of East-European Platform's territory, with regard to possibilities of diamondiferousness within the frame of this work, there was put the principle of summing up favourable indications, revealed first of all during processing of space photography materials. In the final variant within the whole territory six "space" and one "geophysical" informative indication were taken into account. Among others the following ones were referred to as informative: zones of radial and arc elements composing East-European system and the knots of their intersection; chief elements of different ovoid-radial structures and various combinations of composing them elements; areas inside ring structures of average size $(150-200 \mathrm{~km})$, stipulated by hearth processes in mantle and crust. Summing up was carried out within rated cells of $50 \times 50 \mathrm{~km}$ size.

The most part of anomaly informative cells located in sufficiently compact groups of 7 to 18 in each. All in all within the East-European Platform (within the borders of CIS, Baltic countries and Finland) there were delineated 26 different in size areas, 15 of which are characterized by availability within their limits of sufficiently large number of located to each other cells with anomalous sum of favourable indications.

Generalization of data allows to make a preliminary conclusion that the sites of the first turn, where one can hope for fast achievement of positive results while carrying out works of subsequent stages, locate in Arkhangel'sk, Voronezh, Novgorod-Tver' and Bryansk areas within the borders of Russia, Obruch-Zhitomir, Sumskaya and Donetsk areas within the Ukrain, Minsk within Belarus'. Saransk-Nizhnegorodskaya, Kol'skaya, Petrozavodskaya, Kirovograd-Cherkasskaya, Latviyskaya, Samarskaya, Pecherskaya, Finlyandskaya areas may be considered in the second turn, while the parameters, by which they are included into this group, are different and vary from considerable post-ore section of the territory till significant in thichness cover of overlaying sediments.

Onezhskaya, Tmanskaya, Vologodskaya and Saratovskaya areas are enlisted by the sum of applied parameters to the third turn. The developed by us technology [2] presupposes carrying out within the allocated areas the next stage of forecast works with application of distant sounding materials of much higher resolution (1:1000 000 - 1:500 000 scale), which will enable to more clearly reveal the elements of the structures controlling the ways of mantle rocks' migration within the boundaries of the region, as well as determine the sites where localization of kimberlite fields is most probable. The size of perspective sites therewith reduces by an order (tens - first hundreds of kilometres), which will make it possible to perform the complex of surface prospecting works with the least time and material expenses.

\section{References}

1. Vaganov, V.I., Varlamov V.A., Feldman, A.A., et al., 1995, Forecast-prospecting systems for diamond deposits: Home geology, ${ }^{1}$ 3. P. 42-52.

2. Serokurov, Y.N., 1995, Application of space sounding materials during forecast and prospecting of primary diamond deposits: Ores and metals, ${ }^{1} 6$, P. 30-38. 